\title{
Justice In Judges' Decisions On Criminal Cases According To The View Of Progressive Law
}

\section{Ari Indra David ${ }^{*}$ and Maryanto**)}

* Chairman of DPC Congress of Indonesian Advocates, Bogor Raya e-mail: hamibogorraya82@gmail.com

**) Faculty of Law Universitas Islam Sultan Agung

\begin{abstract}
This study aims to find out and examine justice in judge decisions in criminal cases according to the view of progressive law. This study uses a normative juridical approach, which is descriptive analysis. The data used is secondary data obtained through literature study, which is then analyzed qualitatively. The results of this study are that justice in judge decisions in criminal cases according to the view of progressive law must be able to provide spiritual enlightenment for litigants, and strengthen social cohesion in social relations. Progressive judges will use the best law in the worst circumstances. A fair decision in the view of progressive law is a decision that is not merely legalistic in nature, does not only fulfill legal formalities, has a vision for the future, and is partial and sensitive to the fate and condition of the nation and state.
\end{abstract}

Keywords: Judge; Progressive Law; Justice; Decision.

\section{Introduction}

In Article 1 paragraph (3) of the 1945 Constitution of the Republic of Indonesia it is stipulated that: "The State of Indonesia is a state of law". Indonesia as a state of law, then both in the administration of the state and in the life of the nation and state must not deviate from the law. Obeying the law is an obligation for all Indonesian people for the sake of creating security and order. ${ }^{1}$ The state must also uphold the rule of law. Law enforcement is one of the parameters in the success of the rule of law. ${ }^{2}$

The rule of law is a state that guarantees justice for its citizens. Every citizen has the same position before the law. Therefore, there should be no discrimination for justice seekers. Protecting the entire Indonesian nation is a duty that must be carried out by the government whose obligations are the basic rights of citizens without exception. ${ }^{3}$

\footnotetext{
${ }^{1}$ Jawade Hafidz Arsyad dan Dian Karisma, 2018, Sentralisasi Birokrasi Pengadaan Barang \& Jasa Pemerintah, First edition, Sinar Grafika, Jakarta, p. 23.

${ }^{2}$ Sri Endah Wahyuningsih dan Rismato, Januari-April 2015, Kebijakan Penegakan Hukum Pidana Terhadap Penanggulangan Money Laundering Dalam Rangka Pembaharuan Hukum Pidana Di Indonesia, Jurnal Pembaharuan Hukum, Vol. II No. 1, Faculty of Law Universitas Islam Sultan Agung, Semarang, url : http://jurnal.unissula.ac.id/index.php/PH/article/view/1414/1087, p. 46-47. ${ }^{3}$ Farhan Munirus Su'aidi dan Abdullah Arief Cholil, Desember 2019, Law Protection on Wife Whose The Claims Fall Due To Husband Refuse His Recompensation On Implementing Of Divorce Pledge, Jurnal Daulat Hukum, Vol. 2 No. 4, Faculty of Law, Universitas Islam Sultan Agung Semarang, url : http://jurnal.unissula.ac.id/index.php/RH/article/view/8367/3897, p. 548.
} 
The cases that are now decided are more controversial and have received criticism from the public. The law seems to favor the upper class people over the common people. More precisely, the law pointed downwards, but blunted upwards. For example, in the case of Granny Minah, who picked 3 cocoa pods, and was sentenced to 1 month and 15 days in prison with a probationary period of 3 months. The judge's decision is very far from humanity and justice, and only prioritizes legal certainty.

Cases that are criticized by the public are decisions that are far from a sense of justice, thus making the public lose confidence in judges. It is true, judges only carry out orders that are in the law. Some judges think that the decision is fair if it is in accordance with the law or is formal. The judge should see the condition of the community to be able to make a decision that is said to be fair to the community.

It is not easy for judges to make decisions, because ideally the decision must contain the ideals of the legal basis, which includes 3 (three) elements, namely justice, legal certainty, and expediency. Judges must consider and apply these three elements proportionally, so that quality decisions can be made and meet the expectations of justice seekers. However, it is not easy to synergize these three elements, and sometimes they contradict each other, for example between justice and legal certainty.

The judge's decision in a criminal case, can be in the form of a criminal sentence if the actions of the perpetrator of the crime are proven legally and convincingly, the decision on acquittal from a criminal act (vrijspraak) in the event that according to the results of the examination at trial, the defendant's guilt is not proven legally and convincingly or in the form of the decision is free from all lawsuits (onslaag van alle rechtsvervolging), in the event that the defendant's actions as charged are proven, but the act does not constitute a criminal act. 4

The facts at the trial are the basis of the judge's decision, but if the judge only looks at the law in making a decision, then injustice can occur, because law is different from justice so that people are dissatisfied even though the decision handed down is in accordance with the article of the law

The dissatisfaction of justice seekers with the judge's decision is due to the non-fulfillment of the values of justice. Judges do not really explore legal values and a sense of justice that live in society on the grounds that they are bound by rigid formal legal rules and are no longer appropriate. Here the judge is only a mouthpiece of the law or the judge puts forward a positivistic paradigm (legal positivism).

The teaching of legal positivism is opposed by the teachings of sociological jurisprudence. The teaching put forward by Eugen Ehrlich and Roscoe Pound states that: "Good law is law that is in accordance with the law that lives in society" (the center of gravity of legal development is not in legislation, nor in juristic, nor in judicial decision, but in society). 5

This is in accordance with the provisions of Article 5 of Act No. 48 of 2009 concerning Judicial Power, which states that: Judges and constitutional judges are

\footnotetext{
${ }^{4}$ Ahmad Rifai, 2018, Penemuan Hukum Oleh Hakim Dalam Perspektif Hukum Progresif, Fourth edition, Sinar Grafika, Jakarta, p. 95.

5Widodo Dwi Putro, 2011, Kritik Terhadap Paradigma Positivisme Hukum, First edition, Genta Publishing, Yogyakarta, p. 227.
} 
obliged to explore, follow, and understand legal values and a sense of justice that live in society.

The positivistic way of thinking of judges must be changed. This is where the importance of the presence of progressive law, with the motto of pro-justice law and pro-people law. Progressive law places the dedication of legal actors at the forefront. Lawyers are required to prioritize honesty and sincerity in carrying out the law. They must have empathy and concern for the suffering experienced by the people and this nation. The interests of the people (welfare and happiness) must be the point of orientation and the ultimate goal of implementing the law. ${ }^{6}$

Progressive law is not just applying rules and only to fulfill procedures, but law that must be seen as a human problem as a whole. Progressive law is a law that is needed for humans, both in the action of interaction with fellow humans and humans with the universe, namely the social environment and the natural surroundings. Progressive law is a law that essentially regulates human behavior through created legal norms that prioritize justice and essential happiness for life. ${ }^{7}$

The presence of progressive law is very important in the context of law enforcement, especially for judges in court. Judges are central figures in the judicial process. A fair judge's decision will be the pinnacle of wisdom for solving legal problems that occur in state life. The judge's decision pronounced with (title) irahirah: "For Justice Based on God" shows the obligation to uphold justice that is accountable vertically to God Almighty, as well as horizontally to fellow human beings. ${ }^{8}$

The concept of progressive law, departs from the concept that the law is for humans, which includes the values of truth and justice which are the point of legal discussion, so that ethical and moral factors cannot be separated from the discussion. So, progressive law explicitly links legal factors, humanity with morality. For this reason, in every case that is brought to him, a judge must remain guided by the applicable laws and regulations, while still upholding the values of humanity, truth and justice. ${ }^{9}$

The purpose of this study is to find out and examine justice in judge decisions in criminal cases according to the view of progressive law.

\section{Research Methods}

The type of research used in writing this legal journal is normative juridical. Normative juridical research is research that is focused on examining the application of rules or norms in positive law, ${ }^{10}$ which in this case relates to justice in judge decisions in criminal cases according to the view of progressive law. This research is descriptive analysis, because the researcher wishes to describe or explain the subject and object of research, which then analyzes and finally draws

\footnotetext{
${ }^{6}$ M. Syamsudin, 2012, Konstruksi Baru Budaya Hukum Hakim Berbasis Hukum Progresif, First Edition, Kencana Prenada Media, Jakarta, p. 255.

7Ibid., p. 237.

8Ibid., p. 256.

${ }^{9}$ Ahmad Rifai, op.cit., p. 92-93.

10Jhonny Ibrahim, 2011, Teori dan Metodologi Penelitian Hukum Normatif, Bayumedia, Malang p. 295.
} 
conclusions from the results of the study. ${ }^{11}$ The data used in this research is secondary data. According to the data that has been obtained during the research by reading library books, then it is analyzed. The analysis used in this research is qualitative data analysis.

\section{Results and Discussion}

In Article 1 paragraph (8) of the Criminal Procedure Code (KUHAP) it is stated that: "Judges are district court officials who are authorized by law to try". Thus, the function of a judge is someone who is authorized by law to conduct or adjudicate every case delegated to the court. 12

Djoko Prakoso argued that adjudicating is a human struggle to realize the law, so judging without a human relationship is essentially impossible. Therefore, adjudicating without a human relationship between the judge and the accused is often perceived as treating an injustice. ${ }^{13}$

Basically, the task of the judge is to make decisions in every case or conflict that is faced with him, to determine matters such as legal relations, the legal value of behavior, as well as the legal position of the parties involved in a case, so as to be able to resolve disputes or conflicts impartially. Based on the applicable law, the judge must always be independent and free from the influence of any party, especially in making a decision. A judge is a state judicial official who is authorized by law to adjudicate a case before him. ${ }^{14}$

Decisions in the judiciary are acts of judges as authorized state officials which are pronounced in a trial open to the public and made in writing to end the dispute that is faced by the parties to him. ${ }^{15}$

In making a decision, there will be legal discoveries made by the judge when examining a case, the judge in carrying out his duties and authority to examine, hear, and then make a decision must be based on applicable law and also based on his belief, not based solely on legal logic.

If it is based on a conservative legal paradigm, then in the legal findings made by the judge, it appears that the judge only confirms that the law can be applied to the event, then the judge applies it according to the law. Thus, the discovery of law in this case, is nothing but the application of laws that occur by force or syllogisms. So, in this case the judge does not find a new law, and only applies the law or the judge is only a trumpet of the law. In the conservative paradigm of law discovery, law and justice are only to prevent the decline of morals and values. ${ }^{16}$

\footnotetext{
11Mukti Fajar ND dan Yulianto Achmad, 2010, Dualisme Penelitian Hukum Normatif dan Empiris, Pustaka Pelajar, Yogyakarta, p. 183.

${ }^{12}$ Lilik Mulyadi, 2010, Putusan Hakim dalam Hukum Acara Pidana: Teori, Praktik, Teknik Penyusunan dan Permasalahannya, Citra Aditya Bakti, Bandung, p. 120.

13Mahrus Ali, 2013, Melampaui Positivisme Hukum Negara, First edition, Aswaja Pressindo, Yogyakarta, p. 44.

${ }^{14}$ Ahmad Rifai, op.cit., p. 3.

15Maruarar Siahaan, 2012, Hukum Acara Mahkamah Konstitusi Republik Indonesia, Sinar Grafika, Jakarta, p. 201.

${ }^{16}$ Ahmad Rifai, op.cit., p. 47-48.
} 
What is written in the legal text (law) or what has been made by the legislature, can only be voiced by the judges. Judges become readers and deliver the contents of legal texts (laws). It can't be more than that. This principle prevents the occurrence of a possible punishment (punishment) outside of what is stated in a legal text (law). ${ }^{17}$

When accepting the law as a final scheme, the law no longer appears as a solution to humanitarian problems, but humans are forced to fulfill the interests of legal certainty. ${ }^{18}$

Using a conservative legal paradigm, justice will be difficult to obtain, so such a paradigm must be changed to a progressive legal discovery paradigm. In the paradigm of progressive legal discovery, law and justice become tools for making social changes.

The discovery of progressive law, departs from the concept of progressive law, that the law is for humans, which includes the values of truth and justice which are the point of legal discussion, so that ethical and moral factors cannot be separated from the discussion. Progressive legal discoveries explicitly link legal, humanitarian, and moral factors, so that legal discoveries are made by judges within the framework of carrying out their judicial duties, which in the end the judge will make his decision. The characteristics of progressive legal discovery are: 19

- The discovery of the law based on the judge's own appreciation guided by his views or thoughts independently, based on the view that the law exists to serve humans;

- The discovery of law that relies on legal values, truth, and justice, as well as ethics and morality;

- The discovery of laws that are able to create new values in people's lives, or carry out engineering in a society that is in accordance with the times and technology as well as the conditions of society.

The discovery of progressive law will be closer to the value of community justice. Justice theory is the idea that all people want to be treated fairly, and thus compare their own contributions and rewards with those of their co-workers, to determine whether they have been treated fairly, essentially achieving the will to be treated fairly. ${ }^{20}$

Moreover, Indonesia as a country that upholds the law and human dignity in relation to the law and the government must enforce the law without exception. In the 5th Pancasila principle which reads: "Social justice for all Indonesian people", it can be explained that in such cases, one of them relates to the law which is the right of the Indonesian people to justice in truth. ${ }^{21}$

\footnotetext{
${ }^{17}$ E. Fernando M. Manullang, 2019, Legisme, Legalitas dan Kepastian Hukum, Edisi Kedua, Third edition, Kencana Prenadamedia Group, Jakarta, p. 102.

18Faisal, 2012, Menerobos Positivisme Hukum, Kritik Terhadap Peradilan Asrori, Second edition, Gramata Publishing, Bekasi, p. 135.

${ }^{19}$ Ahmad Rifai, op.cit., p. 48.

${ }^{20}$ Ferry Irawan Febriansyah, 2016, Keadilan Berdasarkan Pancasila (Dasar Filosofis dan Ideologis Bangsa), First edition, Deepublish, Yogyakarta, p. 38.

${ }^{21}$ Lailatul Nur Hasanah dan Sri Endah Wahyuningish, Desember 2019, The Application of Justice Principles Of Rapid Simple Fee In Criminal Justice System In The State Court (Case Study in State court
} 
As mentioned, law enforcement is at the same time an indicator of the rule of law. ${ }^{22}$ Consistent law enforcement will provide a sense of security, justice and certainty. ${ }^{23}$ Law enforcers are required to carry out their duties in accordance with the mandate of laws and regulations that lead to decisions with substance in the form of justice for the parties. ${ }^{24}$

Aristotle in his Rhetorica distinguishes justice in 2 (two) kinds, namely: 25

- Distributive justice (justitia distributive) as justice that gives to each person based on their services or distribution according to their respective rights; and

- Cumulative justice (justitia cummulativa) as justice received by each member regardless of the merits of each. This cumulative justice is based on transactions (sunalla gamata) whether voluntary or not.

The main problem in the implementation of law and justice is human beings, so the main human problem in the context of a fair legal process is justice. Hans Kelsen, who was a pioneer for pure legal teachings, emphasized that the notion of law must be distinguished from the notion of justice. The answer to the question of the validity of the law so that its rules must be implemented and obeyed depends very much on the relationship established between law and justice. This relationship is basically in accordance with Gustav Radbruch's view that the law may be unfair, but the law is only law because it wants to be fair. Nevertheless, ${ }^{26}$

As it is known that legal life in Indonesia still raises public concern and disappointment. The law is not able to bring justice to all. Law enforcement is like a kitchen knife, sharp down and blunt up. The law is repressive when dealing with the poor. On the other hand, for people with money (the haves), the law is protective and impartial. The law that takes sides will not be able to bring about justice in society. The legal principle that everyone is equal before the law (equality before the law), is changed by society to "but not before law enforcement". ${ }^{27}$

\footnotetext{
of Pati), Jurnal Daulat Hukum, Vol. 2 No. 4, Faculty of Law Universitas Islam Sultan Agung, Semarang, url : http://jurnal.unissula.ac.id/index.php/RH/article/view/8353/3910, p. 610.

${ }^{22}$ Alvi Syahri, September 2020, Law Enforcement against Policies Who Breached the Code of Conduct, Jurnal Daulat Hukum, Vol. 3 No. 3, Faculty of Law Universitas Islam Sultan Agung, Semarang, url : http://jurnal.unissula.ac.id/index.php/RH/article/view/11238/4399, p. 313.

${ }^{23}$ Anggrin Gayuh Praptiwi dan Lathifah Hanim, September 2019, Effectiveness And Role Of The Food Duty Unit Of Police Region Of Central Java In Law Enforcement In The Field Of Food In The Regional Law Of POLDA Central Java, Jurnal Daulat Hukum, Vol. 2 No. 3, Faculty of Law Universitas Islam Sultan Agung, Semarang, url : http://jurnal.unissula.ac.id/ index.php/ RH/article/view/5669/3416, p. 387. ${ }^{24}$ Iwan Setiyadi dan Sri Kusriyah, Juni 2019, Law Enforcement Process Analysis By Agencies Of Provos Indonesian National Police (Inp) On Discipline Violation In The Form OfCrime By Police Members (Case Study In National Police Headquarter), Jurnal Daulat Hukum, Vol. 2 No. 2, Faculty of Law Universitas Islam Sultan Agung, Semarang, url : unissula.ac.id/index.php/RH/article/view/5424/3345, p. 204.

${ }^{25}$ Teguh Prasetyo dan Abdul Hakim Barkatullah, 2012, Filsafat, Teori, dan Ilmu Hukum, Pemikiran Menuju Masyarakat yang Berkeadilan dan Bermartabat, Rajawali Pers, Jakarta, p. 368.

${ }^{26}$ Abdul Latif, 2014, Hukum Administrasi Dalam Praktik Tindak Pidana Korupsi, First Edition, Kencana Prenada Media Group, Jakarta, p. 157 and 158.

${ }^{27} \mathrm{Abu}$ Rohkmad, 2012, Hukum Progresif, Pemikiran Satjipto Rahardjo Dalam Perspektif Teori Maslahah, First edition, Program Pasca Sarjana IAIN Walisongo Semarang dan Pustaka Rizki Putra, Semarang, p. 2 and 3.
} 
The term progressive law in various contexts is closely related to the initiator, fighter and developer of this idea, namely Satjipto Rahardjo. Although not exactly the same, Van Gerven in his book "Theorie en Praktijk van de Rechtsvinding" has introduced a progressive stream of legal discovery. If that's true, Satjipto Rahardjo has succeeded in developing the idea of a progressive school of law to become more complete, systematic and close to perfection. ${ }^{28}$

The idea of progressive law carries the banner of law for humans. The characteristics of progressive law are in the form of rule breaking, legal leaps aimed at law enforcers to bring justice to the community (bringing justice to the people) through 3 (three) main activities, namely: ${ }^{29}$

- Using spiritual intelligence to wake up from legal adversity provides an important message for us to dare to seek new paths (rule breaking) and not to let ourselves be restrained by old ways, implementing old and traditional laws that clearly hurt the sense of justice more;

- The search for deeper meaning should be a new measure in carrying out the law and having a state of law. Each party involved in the law enforcement process is encouraged to always ask one's conscience about the deeper meaning of the law;

- The law should be carried out not only according to logical principles, but with feelings, care and involvement (compassion) for weak groups.

According to Artidjo Alkostar, to describe progressive judges, it cannot be separated from high standard qualifications which include mastery of scientific competence, professional skills, and personality qualities attached to judges as law enforcement subjects. From this predicate, ethical consequences are required for the emergence of judges' decisions that show moral, intellectual, and emotional intelligence. The resulting decision can provide spiritual enlightenment for litigants, and strengthen social cohesion in the social system of society. ${ }^{30}$

The role and duty of judges is not only to read letters in the laws made by the legislature, but in their decisions to bear the responsibility of being the voice of common sense and articulating the spirit of justice in the complexities and dynamics of people's lives. Progressive judges will use the best law in the worst circumstances. ${ }^{31}$

Suteki stated that a judge can ignore the written law (statutory law/state law) if the written law does not in practice fulfill the sense of justice as expected by the justice-seeking community. ${ }^{32}$

The portrait of progressive law enforcement, among others, refers to the existence of law enforcement figures, who are oriented towards the value of justice and the value of truth. An example of a progressive judge's decision is the judgment of Judge Davide in the Philippines in the Oposa case at the Supreme Court level in 1993, which ruled that there is a right of litigation for the unborn generation to file

\footnotetext{
28Ibid., p. 6.

${ }^{29}$ Suteki, 2014, Perkembangan Ilmu Hukum dan Implikasi Metodologinya Dalam Metodologi Penelitian Hukum, Bahan Ajar, Program Doktor Ilmu Hukum Universitas Diponegoro, Semarang, p. 15.

${ }^{30}$ M. Syamsudin, op.cit., p. 256.

31Ibid., p. 257.

32Suteki, 2013, Desain Hukum Di Ruang Sosial, First edition, Thafa Media Yogyakarta dan Satjipto Rahardjo Institute Semarang, p. 192.
} 
a lawsuit on the basis of the principle of intergenerational justice. In the history of Islam, progressive law enforcement was demonstrated by Caliph Umar bin Khatab who imposed reverse evidence for government officials suspected of committing corruption. ${ }^{33}$

A progressive-minded judge, makes himself a part of society, and will always do things to improve, not just spell the law. A progressive judge will always put an ear to the beating heart of his people.

There was an interview with a "little judge", but it deserves to be a role model for "big judges" (Kompas, February 2, 2004). He said morality alone is not enough, the most important thing is courage, said Teguh Haryanto. Indeed, to create a progressive court requires not only a moral commitment, but also one thing and having the courage to display that commitment is another. ${ }^{34}$

For progressive law, the law is for humans and not vice versa, and the law does not exist for itself, but for something wider, namely for human dignity, happiness, welfare, and human glory. ${ }^{35}$

Acceptance of human factors, will bring progressive law to concern for human behavior factors (behavior, experience). In the positivist legal paradigm, human position is for law and legal logic, so humans can be forced to be included in law. On the other hand, in a progressive legal paradigm, it places the law for humans. If the human factor which includes truth and justice has become a point of legal discussion, then the ethical and moral factors will naturally be dragged into it. Ethical and moral factors are very necessary in building the concept of progressive law, because ethics and morals will speak right and wrong or good and bad, which are directly attached to humans. If a person does not have ethics and morals, then he is the same as other creatures like animals. ${ }^{36}$

The progressive law contains a very strong human morality. If human ethics or morals have faded, then law enforcement will not be achieved, so that building a society for prosperity and human happiness will not be realized. The development of the foundation of this mental awareness is by improving morals, moral development or character building of the community so that it becomes a moral society with high morals, so that a peaceful society can be built, a just and prosperous society.

In progressive law, a judge in making a decision to be handed down is not just carrying out procedures and then applying the articles of the law that are suitable for the events or events to be punished, but sociologically (factually) many social variables are involved. . Indeed, in the process of law enforcement, the procedures and articles of the law cannot be ignored, because they are the main means/equipment. However, it must be borne in mind that these means and equipment are not what the law really wants to achieve. The procedures and articles are only tools and equipment that are expected to lead law enforcers to arrive at the real legal goals. ${ }^{37}$

\footnotetext{
33Ibid., p. 257-258.

${ }^{34}$ Satjipto Rahardjo, 2006, Membedah Hukum Progresif, Kompas, Jakarta, p. 58.

${ }^{35}$ Ahmad Rifai, op.cit., p. 45.

36 Ibid.

${ }^{37}$ M. Syamsudin, op.cit., p. 258-259.
} 
This provision means that judges, as formulators and explorers of legal values that live in society, must go into the midst of society to recognize, feel, and be able to explore the feelings of law and the sense of justice that live in society, so that in facing a case or case that is included in a statutory provision, and it turns out that the judge observing the provisions of the law is not in line with the values of truth, justice, as well as morality and ethics, then the judge can override the provisions in the law, and impose decisions that are in accordance with legal values and a sense of justice that live in society. ${ }^{38}$

The method of legal discovery that is in accordance with the characteristics of progressive legal discovery is a method of legal discovery that is visionary and courageous in making a breakthrough (rule breaking) by looking at the development of society in the future, but still guided by truth and justice as well as taking sides and being sensitive to fate and circumstances the nation and state, so that it can bring prosperity and prosperity to the community and can also bring the nation and state out of adversity and social instability. ${ }^{39}$

Based on this, the judge's decision in accordance with the progressive legal discovery method is: ${ }^{40}$

- Judges' decisions are not merely legalistic in nature, that is, they only serve as mouthpieces for the law (la bouche de la loi) although judges should always be legalistic because their decisions are still guided by the prevailing laws and regulations;

- The judge's decision does not only fulfill legal formalities or just maintain order, but the judge's decision must function to encourage improvement in society and build social harmonization in the association;

- Decisions of judges who have a visionary vision, who have the moral courage to make legal breakthroughs (rule breaking), where in the event that a provision of the existing law is contrary to the public interest, decency, civilization, and humanity, namely the values that live in society, the judge is free and authorized to take contra legem, namely taking decisions that are contrary to the articles of the law in question, with the aim of achieving truth and justice;

- The judge's decision is impartial and sensitive to the fate and condition of the nation and state, which aims at increasing welfare for the prosperity of the community and bringing the nation and state out of adversity in all areas of life.

Such a judge's decision is expected to encourage improvements in society and build social harmonization in the association between community members, and can be used as a source of legal reform, development of law and legal science, and can also be used as study material in legal science.

\section{Closing}

Justice in judge decisions in criminal cases according to a progressive legal view must be able to provide spiritual enlightenment for litigants, and strengthen social cohesion in the social system of society. Progressive judges will use the best

\footnotetext{
${ }^{38}$ Ahmad Rifai, op.cit., p. 137.

39 Ibid.

40Ibid., p. 137-138.
} 
law in the worst circumstances. A fair decision in the view of progressive law is a decision that is not merely legalistic in nature, does not only fulfill legal formalities, has a vision for the future, and is partial and sensitive to the fate and condition of the nation and state.

For judges and other law enforcers, in the context of upholding law and justice, they need to be more forward-thinking (visionary) by using a progressive legal approach, with an emphasis on truth and humanity. This will be closer to the justice that the community desires, rather than just relying on the law.

\section{References}

\section{Journal}

[1] Alvi Syahri, September 2020, Law Enforcement against Policies Who Breached the Code of Conduct, Jurnal Daulat Hukum, Vol. 3 No. 3, Faculty of Law Universitas Islam Sultan Agung, Semarang, url : http://jurnal.unissula.ac.id/index.php/RH/article/view/11238/4399.

[2] Anggrin Gayuh Praptiwi dan Lathifah Hanim, September 2019, Effectiveness And Role of The Food Duty Unit Of Police Region Of Central Java In Law Enforcement In The Field Of Food In The Regional Law Of POLDA Central Java, Jurnal Daulat Hukum, Vol. 2 No. 3, Faculty of Law Universitas Islam Sultan Agung, Semarang, url : http://jurnal.unissula.ac.id/ index.php/ RH/article/view/5669/3416.

[3] Farhan Munirus Su'aidi dan Abdullah Arief Cholil, Desember 2019, Law Protection on Wife Whose The Claims Fall Due To Husband Refuse His Recompensation On Implementing Of Divorce Pledge, Jurnal Daulat Hukum, Vol. 2 No. 4, Faculty of Law Universitas Islam Sultan Agung, Semarang, url : http://jurnal.unissula.ac.id/index.php/ RH/article/view/8367/3897.

[4] Iwan Setiyadi dan Sri Kusriyah, Juni 2019, Law Enforcement Process Analysis By Agencies Of Provos Indonesian National Police (Inp) On Discipline Violation In The Form of Crime By Police Members (Case Study In National Police Headquarter), Jurnal Daulat Hukum, Vol. 2 No. 2, Faculty of Law Universitas Islam Sultan Agung, Semarang, url : http://jurnal. unissula.ac.id/index.php/RH/article/view/5424/3345.

[5] Lailatul Nur Hasanah dan Sri Endah Wahyuningish, Desember 2019, The Application of Justice Principles Of Rapid Simple Fee In Criminal Justice System In The State Court (Case Study in State court of Pati), Jurnal Daulat Hukum, Vol. 2 No. 4, Faculty of Law Universitas Islam Sultan Agung, Semarang, url : http://jurnal.unissula.ac.id/index. php/RH/article/view/8353/ 3910.

[6] Sri Endah Wahyuningsih dan Rismato, Januari-April 2015, Kebijakan Penegakan Hukum Pidana Terhadap Penanggulangan Money Laundering Dalam Rangka Pembaharuan Hukum Pidana Di Indo-nesia, Jurnal Pembaharuan Hukum, Vol. II No. 1, Faculty of Law Universitas Islam Sultan Agung, Semarang, url : http://jurnal.unissula. ac.id/index.php/PH/article/ view/1414/1087.

\section{Books}


[1] Abdul Latif, 2014, Hukum Administrasi Dalam Praktik Tindak Pidana Korupsi, First edition, Kencana Prenada Media Group, Jakarta.

[2] Abu Rohkmad, 2012, Hukum Progresif, Pemikiran Satjipto Rahardjo Dalam Perspektif Teori Maslahah, First edition, Program Pasca Sarjana IAIN Walisongo Semarang dan Pustaka Rizki Putra, Semarang.

[3] Ahmad Rifai, 2018, Penemuan Hukum Oleh Hakim Dalam Perspektif Hukum Progresif, Fourth edition, Sinar Grafika, Jakarta.

[4] E. Fernando M. Manullang, 2019, Legisme, Legalitas dan Kepastian Hukum, Edisi Kedua, Third edition, Kencana Prenadamedia Group, Jakarta.

[5] Faisal, 2012, Menerobos Positivisme Hukum, Kritik Terhadap Peradilan Asrori, Second edition, Gramata Publishing, Bekasi.

[6] Ferry Irawan Febriansyah, 2016, Keadilan Berdasarkan Pancasila (Dasar Filosofis dan Ideologis Bangsa), First edition, Deepublish, Yogyakarta.

[7] Jawade Hafidz Arsyad dan Dian Karisma, 2018, Sentralisasi Birokrasi Pengadaan Barang \& Jasa Pemerintah, First edition, Sinar Grafika, Jakarta.

[8] Jhonny Ibrahim, 2011, Teori dan Metodologi Penelitian Hukum Normatif, Bayumedia, Malang.

[9] Lilik Mulyadi, 2010, Putusan Hakim dalam Hukum Acara Pidana : Teori, Praktik, Teknik Penyusunan dan Permasalahannya, Citra Aditya Bakti, Bandung.

[10] M. Syamsudin, 2012, Konstruksi Baru Budaya Hukum Hakim Berbasis Hukum Progresif, First edition, Kencana Prenada Media, Jakarta.

[11] Mahrus Ali, 2013, Melampaui Positivisme Hukum Negara, First edition, Aswaja Pressindo, Yogyakarta.

[12] Maruarar Siahaan, 2012, Hukum Acara Mahkamah Konstitusi Republik Indonesia, Sinar Grafika, Jakarta.

[13] Mukti Fajar ND dan Yulianto Achmad, 2010, Dualisme Penelitian Hukum Normatif dan Empiris, Pustaka Pelajar, Yogyakarta.

[14] Satjipto Rahardjo, 2006, Membedah Hukum Progresif, Kompas, Jakarta.

[15] Soeratno dan Lincolin Arsyad, 2003, Metodologi Penelitian Untuk Ekonomi Dan Bisnis, UPP AMP YKPN, Yogyakarta.

[16] Suteki, 2013, Desain Hukum Di Ruang Sosial, First edition, Thafa Media Yogyakarta dan Satjipto Rahardjo Institute Semarang.

[17] — 2014, Perkembangan Ilmu Hukum dan Implikasi Metodologinya Dalam Metodologi Penelitian Hukum, Bahan Ajar, Program Doktor Ilmu Hukum Universitas Diponegoro, Semarang.

[18] Teguh Prasetyo dan Abdul Hakim Barkatullah, 2012, Filsafat, Teori, dan Ilmu Hukum, Pemikiran Menuju Masyarakat yang Berkeadilan dan Bermartabat, Rajawali Pers, Jakarta.

[19] Widodo Dwi Putro, 2011, Kritik Terhadap Paradigma Positivisme Hukum, First edition, Genta Publishing, Yogyakarta. 